\begin{tabular}{c} 
International Journal of Engineering \& Technology, 7 (4) (2018) 2209-2212 \\
International Journal of Engineering \& Technology \\
SPC \\
Website: $\begin{array}{c}\text { ww. sciencepubco.com/index.php/IJET } \\
\text { doi: } 10.14419 / \text { ijet.v7it.17863 } \\
\text { Research paper }\end{array}$ \\
\hline
\end{tabular}

\title{
Factors impeding the industrialized building system (IBS) implementation of building construction in Malaysia
}

\author{
Massofia Md. Ali ${ }^{1}$, Nor Haslinda Abas ${ }^{2 *}$, Haryanti Mohd Affandi ${ }^{3}$, Nor Ain Abas ${ }^{4}$ \\ ${ }^{1}$ Ikhmas Jaya Sdn Bhd, Jalan Talalla, Kampung Attap, 50460 Kuala Lumpur \\ ${ }^{2}$ IBS Cluster, Jamilus Research Centre, Faculty of Civil and Environmental Engineering, Universiti Tun Hussein Onn Malaysia, \\ 86400 Batu Pahat, Johor, Malaysia \\ ${ }^{3}$ Department of Teaching and Learning Innovation, Universiti Kebangsaan Malaysia, Bangi, Selangor, Malaysia \\ ${ }^{4}$ Kolej Kemahiran Tinggi Mara Sri Gading, Parit Raja, 86400 Batu Pahat, Johor, Malaysia \\ *Corresponding author E-mail: nhaslin@uthm.edu.my
}

\begin{abstract}
In Malaysian construction industry, Industrialised Building System (IBS) has been introduced to replace the traditional construction method. While the government has been making significant efforts to encourage the IBS adoption, the uptake of IBS in Malaysia construction projects remains low. This study seeks to identify the barriers to the uptake of IBS and to propose the strategies to enhance the implementation IBS in Malaysian housing construction process from the perspectives of consultants. Interviews were conducted with five selected experienced individuals who were working with consultants (civil and structure engineer and quantity surveyor). The results revealed that, lack of knowledge and insufficient skilled workers are the main factors that impede the IBS uptake in Malaysia. Meanwhile, the most strategy proposed by the interviewees is to increase the facilities and incentives in order to expand research and development in IBS.
\end{abstract}

Keywords: Industrialized Building System; IBS; Construction; Barriers of IBS.

\section{Introduction}

Throughout the years, private projects and the huge-scale public have dominated the activities of the Malaysian construction sector, driven by authorities and government shareholder efforts to enforce following five-year plans targeted at turning into a developed nation. The 11th Malaysia Plan (11MP), covering the years between 2016 to 2020 , focuses on transforming the construction industry to be environmentally sustainable, highly productive, environmentally sustainable, with globally competitive players while focused on safety and quality standards, among other economic areas. Detailed under four main strategic thrusts, which are 'internationalisation,' 'environmental sustainability', 'productivity', 'quality, safety and professionalism', 'productivity' and its goals for the sector include the continuation of a separate Construction Industry Transformation Programme (CITP). CITP is covering the same five-year period, which is intended to help the industry meet market demand and drive the industry into the international arena [1]. The introduction of Industrialised Building System (IBS) in Malaysia began in the early 1960's when the Malaysian government proposed IBS pilot project focusing on speeding up the delivery time of the project [2], [3]. IBS is defined as a construction technique in which components are manufactured in a controlled environment in on-site or off-site, transported, positioned and assembled in to structure with minimal additional site works and differs from that of the traditional process [4]. In a press statement by the CIDB general manager of the IBS and mechanisation division, technology development sector, Noraini Bahri, stated that as at $31^{\text {st }}$ December 2015 , only about 70 percent of private projects and 42 percent of public projects in Malaysia use modern IBS technology [5]. Further, when the target of the IBS Roadmap 2011-2015 is to have all public projects to achieve an IBS score of 70 or more, the IBS usage in public projects fell below expectations, with only 24 percent of public projects rate at above RM10 million have an IBS score of 70 or more. To date, as at May 2016, Works Minister, Datuk Fadillah Yusof said that according to CIDB's study in 2014, implementation rate by the private sector is still low at around 14 percent while the 69 percent of government projects used IBS [6].

It could be seen that, while the government has been making significant efforts to increase IBS adoption, the uptake of IBS in Malaysia construction projects remains low. Limited modernisation of construction practices and method is proving in Malaysia's slow uptake of IBS in spite of it is a globally recognised means to enhance productivity [1]. One of the barriers to the uptake is due to the insufficient knowledge and skills among architects, engineers, and contractors. According to Kamar, Alshawi \& Hamid [7], the adoption of IBS system needs enormous effort to transform current construction method and to train the workers with specialising skills such as coordination and assembly. To date, there are many studies conducted to investigate the barriers of IBS implementation in Malaysian construction industry [8-11]. However, most of the studies are either quantitave-based and general in terms of respondents's demographic.

This study suggested that, it is important to investigate the barriers to the IBS adoption from different construction stakeholders such as developers, architects, engineers, contractors, and manufactures, as various stakeholders may have different views or perspectives. Even though there are many studies previously done to investigate the barriers of the IBS uptake whether in Malaysia or other 
countries, most of the studies were only carried out to attain the opinions of the factors that impede IBS uptake from contractors' perspectives [12], [13] not merely from other stakeholder's perspectives. Therefore, this study seeks to identify the barriers to the uptake of IBS from consultants' perspectives such as structural design consultant and quantity surveyor views, to understand in depth the factors that hindrance them in undertaking IBS projects that further affect the negative uptake of IBS in Malaysia. In order to achieve the aim, two objectives have been highlighted, as follows:

i) To identify the barriers to the uptake of IBS in Malaysia's construction industry.

ii) To propose the strategies to enhance implementation IBS in Malaysia's construction industry.

\section{Methodology}

For this study, an interview was conducted to gather in-depth information from consultant's perspective about the barriers to the uptake of IBS and the strategies to increase implementation IBS in Malaysia's construction. The interviews were completed by three (3) methods namely face to face interview, through a phone call and WhatsApp application. Each interview session took around 30 minutes to 1 hour to complete, depending on the method of interview.

Several criteria were used for the selection of the respondents in this interview. The respondents should have working experiences involving Malaysian IBS construction projects. Five (5) respondents were chosen among consultants who are four (4) civil and structure $(\mathrm{C} \& \mathrm{~S})$ engineers and one (1) quantity surveyor. From their experiences, they were asked two questions with regards to the objectives of the study. To achieve objective 1, the first question is, "based on your experience, what is the barrier to the uptake of IBS in Malaysia's construction?'. In addition, to accomplish the objective 2, the second question is "in your opinion, what is the strategy to enhance implementation IBS in Malaysia's construction?"

\section{Results and discussion}

\subsection{Background of respondents}

Table 1 shows the demographic profile of five (5) selected respondents who work as civil and structure $(C \& S)$ engineer and quantity surveyor. As stated in Table 1, respondents had 5 to 11 years of working experiences and at least 3 to 6 years of working experiences on IBS projects. All respondents had experience working in IBS projects.

Table 1: Demographic Profile of Respondents

\begin{tabular}{cllll}
\multicolumn{4}{c}{ Table 1: Demographic Profile of Respondents } \\
\hline ID & $\begin{array}{l}\text { Position in } \\
\text { the } \\
\text { company }\end{array}$ & $\begin{array}{l}\text { Working } \\
\text { experiences }\end{array}$ & $\begin{array}{l}\text { Working } \\
\text { experiences in } \\
\text { IBS project }\end{array}$ & $\begin{array}{l}\text { Company } \\
\text { discipline }\end{array}$ \\
\hline R1 & $\begin{array}{l}\text { C\&S } \\
\text { Engineer }\end{array}$ & 10 years & 6 years & Consultant \\
R2 & $\begin{array}{l}\text { C\&S } \\
\text { Engineer } \\
\text { C\&S }\end{array}$ & 11 years & 3 years & Consultant \\
R3 & $\begin{array}{l}\text { Engineer } \\
\text { C\&S } \\
\text { Engineer } \\
\text { Quantity } \\
\text { Surveyor }\end{array}$ & 5 years & 5 years & Consultant \\
R5 & 5 years & Consultant \\
\hline
\end{tabular}

\subsection{Results of the interview}

Two questions were asked during the interview session with regards to the respondents' opinions on the barriers of IBS uptake in Malaysia and strategies to enhance IBS implementation in Malaysian construction industry. The results of the interview is discussed in the following sections.

\subsubsection{Barriers to the uptake of IBS}

In terms of the barriers in the implementation of IBS, the question: "Based on your experience, what is/are the barrier(s) to the uptake of IBS in Malaysia's construction?" was asked in order to gain information regarding the barriers exist in IBS implementation from consultant's perspective. This question targets to elaborate on how the limitations in the uptake of IBS can be triggered and what the factors are of contributed towards it. The analysis of the interview is presented according to each respondent's answer.

Respondent R1

An experience of $C \& S$ engineer, respondent R1 highlighted that negative perception towards the IBS system due to the poor jointing between the precast element and in-situ structure. It is more on installation jointing between one element to another element, the proper joint width is less than $5 \mathrm{~mm}$. Jointing part needs to be done correctly to avoid the jointing and leakage problem. For example, the wet areas such as toilets will design as in-situ, the gap between the precast element and in-situ element need to grout accordingly in order to minimise leaking and to crack.

Respondents R2

Based on the question, respondent R2 answered that IBS commonly known as particular design based on product or factory copyright. For example, an interlocking unit system owned by the specialist and only the authorised consultant appointed by the factory can do the design and submission. This will cause limitation of authorisation to another consultant to carry the technology widely. Furthermore, respondent R2 mention that IBS implementation requires a firm and very detail design. IBS like a rigid construction and minimal chances to make design changes after the factory had started its production. Any changes of design due to an architect or mechanical and electrical requirement will affect structure production then it will cause installation delayed and end up with construction period enlarged.

Respondent R3

Respondent R3 pointed that that IBS components lack aesthetic values because the scope is limited which it has a standard size. Most of the IBS's product is a basic sub. The designer must follow the size available and if they want to use different size from the market, it will cost more as the factory needs to fabricate the new one. Respondent R3 further explained that lack of acceptance of IBS because it won't allow any alteration, rectification or renovation of the structure in the future. So, it is a problem if there any changes in design.

Also, respondent R3 added that expert or specialist is needed to handle IBS at the site. General workers available in Malaysia mostly practising conventional method ever since. Before IBS is implemented on one project, the team who manage IBS project must be exposed to IBS system first. This is to ensure the project quality can be guaranteed. The IBS system needs skilled monitoring because if the construction happens any mistake, it will be complicated because it cannot be fixed easily.

Respondent R4

From the Respondent R4 perspective, cost issues influence the level of the adoption of IBS in Malaysia's construction industry. IBS is the risky regarding cost and finance, especially for new companies to get involved. This is due to the costly machinery and equipment also all the testing lab as well.

Moreover, respondent R4 expressed that IBS system needs employees who have advanced skills and knowledge. For instance, at the factory, experienced quality control need to ensure casting work done properly and at the site, the experienced installer needs to ensure everything is installed accordingly.

Respondent R5

When respondent R5 were asked about the barriers, respondent R5 stated that lack of IBS manufacturer near the construction site is one the factor impede the uptake of IBS. For example, due to the position of IBS manufacture suppliers especially at East Coast, causing them to take supplies far away from the construction site, thereby they need to bear additional cost for transportation. 
The analysis from the interviews on the barriers to the uptake of IBS implementation in Malaysia from consultant's perspectives is shown in Table 2.

Table 2: Barriers to the Uptake of IBS Implementation

\begin{tabular}{|c|c|c|c|c|c|c|}
\hline $\begin{array}{l}\text { Barriers of Respondent ID } \\
\text { IBS implementation }\end{array}$ & R1 & $\mathrm{R} 2$ & R3 & $\mathrm{R} 4$ & R5 & $\begin{array}{l}\text { Fre- } \\
\text { quency }\end{array}$ \\
\hline Cost issues & & & & $\sqrt{ }$ & $\sqrt{ }$ & 2 \\
\hline Awareness & & & & & & - \\
\hline Negative perceptions & $\sqrt{ }$ & & & & & 1 \\
\hline Knowledge & $\sqrt{ }$ & & $\sqrt{ }$ & $\sqrt{ }$ & & 3 \\
\hline $\begin{array}{l}\text { Project delivery and sup- } \\
\text { ply chain }\end{array}$ & & & & & & - \\
\hline $\begin{array}{l}\text { Requirement for skilled } \\
\text { workers }\end{array}$ & $\sqrt{ }$ & & $\sqrt{ }$ & $\sqrt{ }$ & & 3 \\
\hline Design & & $\sqrt{ }$ & $\sqrt{ }$ & & & 2 \\
\hline
\end{tabular}

From the Table 2, respondent R4 and R5 agreed that cost issues affecting barriers to the implementation of IBS in Malaysia's construction industry. In terms of transport and handling equipment needs, each component is made directly in the factory before being delivered to the construction site for assembly. This is the problems faced by the small trades where they had to hire special machinery and equipment starting from delivery process to the installation process elements. This cost issue is supported by Nawi et al. [14] and CIDB [15], who emphasized out that IBS requires specialized equipment and machinery and it causes financial barriers to the stakeholders.

Moreover, the frequency of analysis result showed that only respondent R1 stated that negative perception is one of the barriers to the uptake of IBS. Negative perceptions of an IBS product are still perceived from past failures regarding complex accommodation which includes leaks and faults, lack of flexibility, use of unfamiliar materials and low-quality end. This negative perception is conceded by Kamar et al. [7], Nawi et al. [14] and Rahman and Omar [16] and. Thanoon et al. [2]. Nawi et al. [17] also indicated that a weakness of IBS lies in its cumbersome jointing and connections techniques that open to sloppy work and errors.

In addition, respondent R1, R3 and R4 claimed that lack of knowledge is the hurdle of the IBS implementation. Previous studies have pointed out that most local professionals such as architects, design consultant and contractors lack technical expertise in structural analysis, the design of prefabricated components and experience of IBS [7], [17], [18]. All practitioners involved, whether designers or contractors, must have sufficient knowledge about the prefabricated components based construction on ensuring successful the adoption of IBS [19].

Respondent R1, R3 and R4 added that insufficient skilled worker can lead to low quality of the components produced which is also consdidered as the main barriers to the implementation of IBS in Malaysia. Installation of IBS should be in a systematic way and done by skilled workers to facilitate installation process especially jointing of the IBS components. This finding confirms with the study by Nawi et al. [20] who postulated that poor jointing of prefabricated walls with in-situ elements or other ready-made might give rise to water seepage problems in IBS high-rise buildings, especially during a torrential downpour in Malaysia.

For the last factor, which is the flexibility of design, respondent R2 and R3 agreed that design for IBS structure is the barriers to implementation of IBS. Due to the size or volume of material has been produced in advance from the factory, the changes in design are insufficient. IBS design as a less attractive, inflexible architecture in terms of design and dimensions and restricting designer creativity.

\subsubsection{Strategies to enhance implementation of IBS}

Regarding the solutions or actions that need to be taken to overcome the barriers identified in question 1, the question 2: "In your opinion, what are the strategies to enhance implementation IBS in Malaysian construction industry?" was asked so that the initiatives for the barriers that stated in question 1 can be determined.
To increase the implementation of IBS in Malaysia's construction, all respondents had admitted that the solution to overcome the barriers should be taken and applied immediately. Therefore, many strategies and measures and have been developed to plan construction industry in the future industry to ensure that it is knowledgeable, internationally competitive and innovative.

Respondent R1

Respondent R1 had suggested that government should expand research and development to increase the flexibility of the IBS elements to meet industry's need and requirements. Respondent R1 added that government should implement IBS as a mandatory to the private sector. The government must take an integrated initiative to further enhance the utilisation of this system in the private sector in order to achieve the nation's development policy. The IBS system is obliged to be implemented by private sectors as it is vital in establishing strong demand and supply for the future of the industry. Respondent R2

Besides that, respondent $\mathrm{R} 2$ had recommended that government should enhance workers knowledge and produce more IBS installation skill workers. This is to avoid the problem when installation IBS components at the site. Respondent R2 also had recommended that IBS design principal should be part of university syllabus. Other than that, respondent R2 added that government should more give incentives to developer, contractor and consultant for IBS implementation to increase the application of IBS in Malaysia's construction.

Respondent [3]

Respondent [3] had suggested government should promote widely through seminars, documentaries, classes and advertisements to the public that they need to aware that IBS system cannot do any alteration, rectification or renovation. Reluctant to follow or lack of awareness will cause trouble in the future such as cracks or structure collapse beyond repair. Awareness is important to plant the idea in people's mind regarding its pros and cons of using IBS system.

Respondent R4

Moreover, respondent R4 had suggested that loan and funding from government or related agencies in order to boost the numbers of new companies to get involved with IBS. Respondent R4 also had suggested that government or related agencies to provide proper training in order to expand knowledge and skills towards the IBS system such as CIDB has recently organised the short course "IBS for professionals" for contractors and Institute of Engineers Malaysia (IEM) provide a course for engineers.

Respondent R5

Respondent R5 had proposed that the authorities need to offer the incentive tax reduction and flexible financing and to IBS manufacturer to encourage the IBS adoption in the construction industry. When the amount of IBS manufacturer is increasing, it will stimulate supply and demand of the use of IBS in the construction sector, thus creating a balanced ecosystem and more sustainable.

The summary of the interviews on the strategies to enhance the implementation of IBS in Malaysia from consultant's perspectives is shown in Table 3. As shown in the table, respondent R1, R4 and R5 had suggested that the critical strategy is government should increase facilities and incentives as to expand research and development on IBS. This approach agreed by Nawi et al. [9] that a testing labs, Research and Development (R\&D) centre and support services are also needed by an IBS company in the private sector. Other than that, government's incentives to give funding to small companies will increase the company's financial capital to increase the use of IBS technology in the future further, indirectly can controls the market price of IBS components thereby reducing the cost of IBS building methods. This is in agreement with Nawi et al. [7] that continued funding and as such only companies which are and stable and stable financially could endure in use the IBS in the highly competitive industry globally and locally. 
Table 3: Strategies to Enhance the Implementation of IBS in Malaysian Construction Industry

\begin{tabular}{lcccccc}
\hline $\begin{array}{l}\text { Respondent ID Strate- } \\
\text { gies }\end{array}$ & R1 & R2 & R3 & R4 & R5 & Frequency \\
\hline $\begin{array}{l}\text { Facilities and incen- } \\
\text { tives }\end{array}$ & $\sqrt{ }$ & $\sqrt{ }$ & & $\sqrt{ }$ & $\sqrt{ }$ & 4 \\
Awareness & & & $\sqrt{ }$ & & & 1 \\
Training & & $\sqrt{ }$ & $\sqrt{ }$ & $\sqrt{ }$ & & 3 \\
\hline
\end{tabular}

Additionally, respondent R2 and R3 recommended that IBS awareness programs should be enlarged to provide awareness to IBS players and public about the benefits and effectiveness of IBS in the construction industry. The CIDB and related parties need to raise the awareness and find a way to educate of developers and contractors or consultants systematically through activities, for example, discussions seminars and workshops [10]. The lack of skilled workers also contributed to the slow adoption of IBS. Therefore, respondent R2, R3 and R4 urge that government or authorities to provide more training programs to all parties involved with Modular Coordination, especially, the architects, engineers, manufacturers and contractors. Majid et al. [21] highlighted that the government should obligate most of the IBS stakeholders to attend in IBS training. This is also supported by Nawi et al. [9] that more intensive training programs are necessary for the specific IBS skills like assembling or integration system.

\section{Conclusion}

Most common barriers to the uptake of IBS in Malaysia are lack of knowledge and skilled workers and it explicitly addresses the least use of IBS in Malaysia's construction industry. Cost issues and lack of varieties in design were second-ranked second barriers to the implementation of IBS. The study found that awareness of IBS system and project delivery and supply chain is not affecting obstacles to the adoption of IBS in Malaysia's construction industry. Meanwhile, several strategies have been highlighted such as facilities and incentives, promote awareness of IBS and training program. The most common approach that may improve in the adoption of IBS perceived by the respondents is facilities and incentives by government to IBS stakeholders. The IBS system does not require a large labour force, but it involves skilled and semi-skilled workforce. Training programmes are important to overcome the shortage of skilled worker in the construction industry, which indirectly can increase the implementation of IBS in Malaysian construction industry.

This study has limitation which is the insufficient number of respondents from consultants. More respondents are required to get more accurate and useful information for the group or individual involved in the construction of IBS to ensure the robustness of the study. There are some suggestions that can be done for future study:

i) The interview should be carried out by adding more respondents among consultants, for example, architects, to determine the barriers and strategies accurately.

ii) A study on the barriers to the implementation of IBS should be expanded to the other stakeholders such as clients, contractor and manufactures.

\section{Acknowledgement}

The results presented in this paper are parts of an ongoing research project. This research was supported by Fundamental Research Grant Scheme (FRGS) (Vot 1579).

\section{References}

[1] CIDB (2015). Construction Industry Transformation Programme (CITP) 2016-2020 Driving Construction Excellent Together. Kuala Lumpur: Construction Industry Development Board.

[2] Thanoon WAM, Lee WP, Kadir MRA, Jaafar MS, Salit MS The Experiences of Malaysia and Other Countries in Industrialised
Building System Proceeding of International Conference Industrialised Building Systems 10-13 September 2003.

[3] Abas, NH, Blismas N, Lingard, H Knowledge-Based Energy Damage Model for Evaluating Industrialised Building System (IBS) Occupational Health and Safety $(\mathrm{OHS})$ Risk The $3^{\text {rd }}$ International Conference on Civil and Environmental Engineering for Sustainability (IConCEES 2015) 2016 1-7.

[4] Junid SMS. Industrialised Building System. Proceedings of UNESCO/ FEISEAP Regional Workshop, Universiti Putra Malysia (UPM) Serdang 1986.

[5] Lee, R IBS Adoption in Malaysia Remains Low The Edge Property 2015, December 31.

[6] Idris AN Minister: IBS To Be Compulsory For Construction Projects in 2018 (2017, March 21) Retrieved from http://www.theedgemarkets.com/article/minister-ibs-be-compulsory-construction-pr.

[7] Kamar KAM, Alshawi M, Hamid ZA Barriers to Industrialized Building System (IBS): The Case of Malaysia. Built and Human Environment 9th International Postgraduate Research Conference 2009 $1-16$.

[8] Nawi MNM, Lee A, nor KM Barriers to Implementation of the Industrialised Building System (IBS) in Malaysia. The Built \& Human Environment Review 42011 22-35

[9] Amin MA, Abas NH, Shahidan S, Rahamt MH, Suhaini NA, Nagapan S, Abdul Rahim R A review on the current issues and barriers of Industrialised Building System (IBS) adoption in Malaysia's construction industry GCoMSE2017 28-29 August 2017 Johor Bahru, Malaysia. IOP Publishing; 2017.

[10] Kamar KAM, Alshawi M Hamid ZA Barriers to Industrialized Building System (IBS): The case of Malaysia. Proceedings of the BuHu 9th International Postgraduate Research Conference (IPGRC), Salford. 2009 1-16.

[11] Mirza SNI Critical Success Factors and Barriers for Industrialized Building System (IBS) Adoption in Construction Project. Bachelor is Degree Thesis. Universiti Malaysia Pahang;2010.

[12] Kamar KAM, Hamid ZA, Dzulkalninea N Industrialised Building System (IBS) construction: Measuring the perception of contractors in Malaysia IEEE Business, Eng. Ind. Appl. Colloq Kuala Lumpur, Malaysia IEEE; 2012 328- 333.

[13] Meynagh MM, Marsono AK, Kamar KAM, Isaabadi MHZ. Main Factors of Contractor Reluctancy to Adopt IBS Projects in Malaysia Australian Journal of Basic and Applied Sciences. 2014 Dec; 8(18) 251-254.

[14] Nawi MNM, Mydin MAO, Nursal AT, Nifa FAA, Bahaudin AY. Payment issues in Malaysia Industrialised Building System (IBS). Adv. in Env. Biol. 20159 185-188.

[15] CIDB 2007 Roadmap Review: Implementing the IBS Roadmap 20032010. Kuala Lumpur: Construction Industry Development Board.

[16] Rahman ABA, Omar, W. Issues and Challenges in the Implementation of Industrialised Building Systems in Malaysia. Proceedings of the sixth Asia-Pacific Structural Engineering and Construction Conference (APSEC). 2006.

[17] Nawi MNM, Radzuan K, Salleh NA, Ibrahim SH. 2014 Value management: A strategic approach for reducing faulty design and maintainability issue in IBS building. Adv. Environ. Biol. 20148 18591864.

[18] Hamid Z, Kamar KAM, Zain M, Ghani K, Rahim AHA Industrialized Building System (IBS) in Malaysia: The Current State and R\&D Initiatives. Malaysia Construction Research Journal (MCRJ) 2008 2(1) 1-13.

[19] Wong SS, Lau LK. Advantages and Setbacks of Industrialized Building System (IBS) Implementation: A Case Study in Sarawak. International Journal of Sustainable Construction Engineering \& Technology. 2015 6(1) 52-61.

[20] Nawi MNM, Lee A, Arif M. The IBS barriers in the Malaysian construction industry: a study in construction supply chain perspective. In Proceedings: Industrialisation in Construction, CIB, Rotterdam, the Netherlands. CIB Publication 2010354 77-92.

[21] Majid TA, Azman MNA, Zakaria SAS, Zaini SS, Yahya AS, Ahamad MSS, Hanafi M H. The Industrialised Building System (IBS) survey report 2008 - Educating the Malaysian construction industry. In 2nd International Conference on Computer Research and $\begin{array}{llll}\text { Development } & \text { (ICCRD 2010). } 2010 \text { 615-619 }\end{array}$ https://doi.org/10.1109/ICCRD.2010.132. 